Article

\title{
Phosphate Sorption onto Structured Soil
}

\author{
Hermin Saki *(D), Haojie Liu $(\mathbb{1}$ and Bernd Lennartz
}

Faculty of Agricultural and Environmental Sciences, University of Rostock, Justus-von-Liebig Weg 6, 18059 Rostock, Germany; haojie.liu@uni-rostock.de (H.L.); bernd.lennartz@uni-rostock.de (B.L.)

* Correspondence: hermin.saki@uni-rostock.de; Tel.: +49-381-3191

Received: 6 December 2019; Accepted: 8 April 2020; Published: 13 April 2020

check for updates

\begin{abstract}
Soil-phosphorus interactions are frequently studied employing the slurry technique, in which soil samples are intensively mixed with phosphate solutions of various concentrations. The result of such experiments is a "phosphate sorption potential" because the thorough mixing of soil and phosphate solution as obtained by overhead or horizontal shaking of the slurry would probably not occur under natural conditions, especially if the soil is structured. Here, we wanted to test the impact of soil structure on phosphorus $(\mathrm{P})$ removal from aqueous solution. Soil aggregates of a defined size class were prepared by carefully sieving the soil. The soil aggregates were individually wrapped in an inert fabric and placed on a sieve, which was lowered into a basin containing a phosphate solution of a given concentration. The decrease of the phosphate solution concentration with time was registered at fixed intervals, and adsorbed amounts were quantified by differences between initial concentrations and concentrations at the time of sampling. Pre-tests on fine earth revealed that sorption was more pronounced in the classical slurry batch experiment than in the approach used in this study. Differences between methods were more pronounced at lower initial phosphate concentrations. The increase in $\mathrm{P}$ sorption in the classical batch experiment continued over $24 \mathrm{~h}$ to $140 \mathrm{mg} \mathrm{kg}^{-1}$, while the adsorbed P amount remained constant $\left(64 \mathrm{mg} \mathrm{kg}^{-1}\right)$ after $6 \mathrm{~h}$ in the diffusion experiment. Interestingly, it was observed that the sorption onto soil aggregates was elevated as compared to unstructured fine earth. The sorption capacity of aggregates was approximately one third higher than that of the fine earth samples according to optimized Freundlich adsorption coefficients. This was unexpected since it was assumed that the soil surface area available for sorption processes is greater or at least far more accessible if the unstructured fine earth is exposed to the phosphate solution. We conclude that if the inner pore space of soil aggregates is readily accessible and diffusion is not hindered, the overall retention capacity of intact aggregates might be higher than that of the disturbed soil because the intra-aggregate pore space can accommodate a certain fraction of phosphate in addition to the adsorbed amount at particle surfaces. The presented experimental approach allows for studying sorption processes in well-structured and fine earth in conditions that perform better compared to the natural situation. Additional testing of the method for different soil types is advisable.
\end{abstract}

Keywords: phosphorus; structured soil; sorption isotherm; soil aggregate; kinetic model; diffusion experiment

\section{Introduction}

The process of phosphate sorption onto soils is of significant relevance, because phosphorus $(\mathrm{P})$ is an essential plant nutrient driving growth and causes environmental problems if released in higher concentrations to water resources [1-3]. The sorption process of phosphate onto soil depends on physical and chemical soil characteristics including clay, organic matter and Al- and Fe-oxides content, soil moisture, $\mathrm{pH}$, and moreover, on the redox conditions at which the sorption process 
takes place [4-8]. While a solid body of literature is available on how soil chemical properties and various soil constituents affect the sorption of phosphate, little is known as to what extent soil physical characteristics, in particular, soil structure, influence the sorption process [9].

Soil aggregates are formed in soil by the arrangement and organization of soil particles, and the tendency of individual soil units, including clay minerals and organic substances, to bind together [10]. The formation of soil peds results in an intra- and inter-aggregate pore space, with an according fractionation of flow pathways for water, gases, and solutes [11,12]. Soil aggregates differ from the fine earth with respect to density, and they are more tortuous because of the dominance of finer pores [13]. The accessibility of the pore space of aggregates for solutes depends on the composition of the soil (clay content) and the pore size classes.

In the majority of batch sorption studies, the adsorbed amount of a compound is indirectly determined by calculating the difference of compound mass prior to and after thorough mixing of the compound solution and a soil sample, taking the soil-solution ratio into account [14]. In cases in which porous substrates are used as an adsorbent, the pore space may accommodate molecules in addition to the actual sorption process, in which a molecule is bound to the surface of soil particles via a variety of binding mechanisms such as Van-der-Waals forces, hydrogen bonding, ion-induced dipole forces, and ion-dipole forces. The release of adsorbed phosphorus from the interior of soil aggregates to the soil solution is a prerequisite to maintain the phosphorus flux to plant roots [15]. Some studies have addressed the importance of diffusion into intra-aggregate pores as the rate-limiting process in the mass transfer of reactive solutes for some ions between sorption site within porous adsorbents and bulk solutions [16-18].

The sorption isotherm is a functional relationship quantifying the adsorbed amount as a function of the solution concentration in a dynamic equilibrium [19-21]. It is intensively used to describe the behavior of Pin a wide range of soils and environmental conditions [22]. Sorption isotherms were obtained by agitating soil samples with solutions of different concentrations [23,24]. Shaking is continued until it is believed that an equilibrium between molecules in the solution and attached to solid surfaces is attained (e.g., $24 \mathrm{~h}$ ) [25]. Empirical as well as more thermo-dynamic-based equations, including Freundlich and Langmuir models, are commonly used to describe the sorption behavior of phosphate in soils [26-28].

The result of a phosphate sorption study is a function of the chosen experimental duration (to obtain equilibrium between dissolved and adsorbed amount), the temperature, the solution:soil ratio, the mixing method, as well as the concentration of initial phosphate solution, among others [23]. All of the mentioned experimental conditions and their effect on phosphate sorption have been thoroughly investigated [29-31]; soil structure effects, however, remain unconsidered. We can currently refer only to a very few phosphate sorption isotherms, which were obtained from structured soil [29,32].

The specific objectives of this study were to (i) establish and examine an applicable method allowing us to quantify sorption effects as caused by soil structure, (ii) characterize the effect of soil structure on phosphate sorption and the effect of initial phosphate concentration on the kinetics of phosphate sorption, and (iii) derive equilibrium sorption isotherms for phosphate onto soil aggregates.

\section{Materials and Methods}

\subsection{Study Site and Soil Samples}

Soil samples were obtained from an agricultural field site, which is located near the city of Rostock, in northeastern Germany. The soil type was classified as a Endostagnic Luvisol, according to the World Reference Base for Soil Resources (WRB) [33]. The climate of the study site ranges from Atlantic to continental, with an average annual precipitation of $660 \mathrm{~mm}$ and an annual mean temperature of $9.1^{\circ} \mathrm{C}$. The study site was under intensive agricultural use, with sugar beet (Beta vulgaris L.) as the dominant crop. 
All experiments were conducted with soil samples from two horizons of the experimental site. Soil aggregates were obtained by letting a soil block fall onto the ground from a $1 \mathrm{~m}$ height. Aggregates were separated by sizes of $4-6 \mathrm{~mm}$ using a standardized sieve. Fine earth in this study refers to disturbed soil samples which were passed through a $2 \mathrm{~mm}$ sieve. Selected physical properties of the soil are listed in Table 1 and some chemical characteristics of the studied site are summarized in Supplementary Table S1. The initial moisture content of fine earth and aggregates samples was $2.62 \pm$ 0.04 and $5.07 \pm 0.6(\mathrm{wt} \%)$ respectively.

Table 1. Soil physical properties of the soil at the study site.

\begin{tabular}{ccccccc}
\hline $\begin{array}{c}\text { Soil } \\
\text { Horizon }\end{array}$ & Depth & $\begin{array}{c}\text { Clay } \\
(\leq 2 \mu \mathrm{m})\end{array}$ & $\begin{array}{c}\text { Silt } \\
(\mathbf{2}-\mathbf{6 3} \boldsymbol{\mu \mathrm { m } )}\end{array}$ & $\begin{array}{c}\text { Sand } \\
(\mathbf{6 3 - 2 0 0 0} \\
\boldsymbol{\mu m})\end{array}$ & $\begin{array}{c}\text { Bulk } \\
\text { Density } \\
\mathbf{9}\end{array}$ & $\begin{array}{c}\text { Organic } \\
\text { Matter } \\
\text { Content } \\
\mathbf{\%}\end{array}$ \\
\hline Topsoil & $\mathbf{c m}$ & & 48.5 & 43.6 & $1.44 \pm 0.32$ & $3.22 \pm 0.04$ \\
Subsoil & $40-70$ & 15.7 & 35.2 & 48.8 & $1.77 \pm 0.02$ & $1.88 \pm 0.03$ \\
\hline
\end{tabular}

\subsection{Classical Batch Experiment (Pre-Test)}

The classical batch experiment for testing phosphate sorption onto soil samples was performed by the agitation of $4 \mathrm{~g}$ of air-dried fine earth with $100 \mathrm{~mL}$ of phosphate solution of various concentrations $\left(1,5,10,20,50\right.$, and $\left.100 \mathrm{mg} \mathrm{L}^{-1}\right)$ using plastic flasks (soil:solution ratio $\left.=1: 25\right)$. The batch containers were shaken using a horizontal shaker with a speed of $200 \mathrm{rpm}$ to homogenize the samples and to promote the reaction within $24 \mathrm{~h}$ at a constant temperature of $22 \pm 1^{\circ} \mathrm{C}$ and a natural $\mathrm{pH}(6.68 \pm 0.12)$. Twenty-four hours has been preferred for sorption experiments providing the $48 \mathrm{~h}$ pre-test experiments for fine earth and soil aggregates (Supplementary Figure S1). After shaking the samples, the suspension was filtered through a $0.45 \mu \mathrm{m}$ nylon mesh. The solution concentration of residual phosphate at equilibrium time was determined by the photometric method [34] and a spectrophotometer (Specord 40 ) at $850 \mathrm{~nm}$. All sorption experiments were carried out with three repetitions, and all calculations are based on the average \pm standard deviation.

The effect of contact time onto P sorption was investigated by sampling the soil-solution mixture at appropriate time intervals ranging from $30 \mathrm{~s}$ to $24 \mathrm{~h}$ and analyzing the solution as described above.

\subsection{Diffusion Experiments}

In comparison to the classical batch experiment, we named the approach tested in this study 'diffusion experiment' as it is believed that diffusion is one of the controlling factors contributing to the overall $\mathrm{P}$ retention. The diffusion experiments to quantify phosphate sorption onto fine earth and aggregates were carried out as a function of time with six initial phosphate concentrations ( 1 , $5,10,20,50$, and $100 \mathrm{mg} \mathrm{L}^{-1}$ ) and a soil:solution ratio of 1:25 using $\mathrm{KH}_{2} \mathrm{PO}_{4}$. A metal mesh was placed into a container in such a way that the soil samples were just in contact with the phosphate solution. A magnetic stirrer adjusted at a low speed of $100 \mathrm{rpm}$ below the mesh ensured a slow motion of the P solution, preventing the establishment of concentration gradients within the solution (Figure 1). Aliquots of the solution $(20 \mathrm{~mL})$ were withdrawn at various contact times ranging from $30 \mathrm{~s}$ to $24 \mathrm{~h}$. The samples were passed through a $0.45 \mu \mathrm{m}$ nylon mesh and the phosphate concentration was determined photometrically [34]. The soil aggregates were individually wrapped using an inert nylon fabric to support cohesion and soil structure. The wrapped soil aggregates were capillary saturated with distilled water for $12 \mathrm{~h}$ prior to the onset of the diffusion experiments (Figure 1) [25]. In the case of fine earth, the sample was placed directly on the metal mesh covered with an inert fabric and lowered into the phosphate solution. The soil:solution ratio was equal for both fine earth and aggregates. Repeated sampling of the solution slightly modified the soil:solution ratio, which was explicitly accounted for in all calculations [25]. 


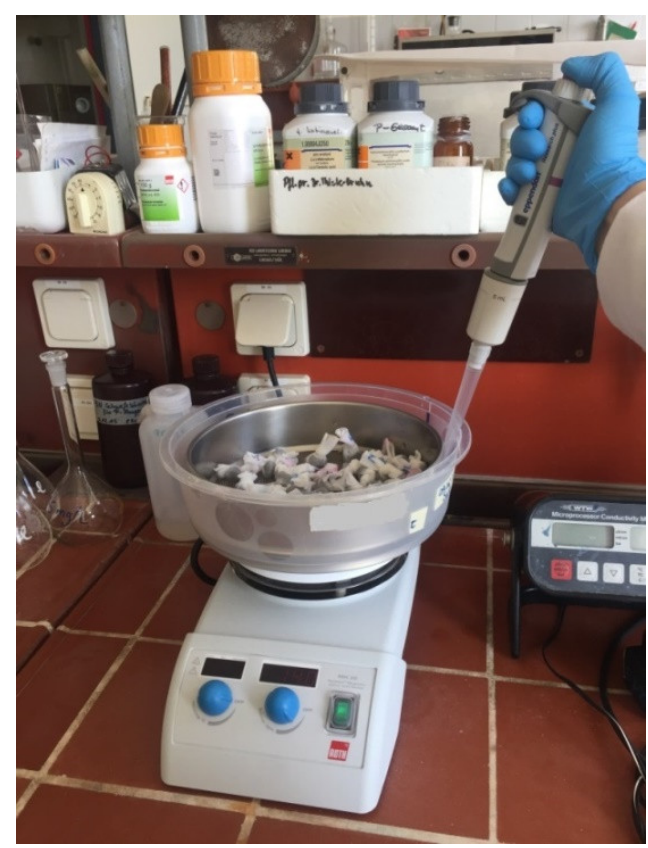

Figure 1. Soil aggregates wrapped in an inert nylon mesh on a sieve during the diffusion experiment.

\subsection{Evaluation of Experimental Data}

Selected mathematical models, including pseudo-first order [35], pseudo-second order [5], and pseudo-nth order equations [36], were used to simulate the sorption kinetics of phosphate onto fine earth and aggregates:

$$
\begin{gathered}
\mathrm{q}_{t}=\mathrm{q}_{\mathrm{e}}\left(1-\mathrm{e}^{-\mathrm{k}_{1} \mathrm{t}}\right), \text { pseudo }- \text { first order } \\
\mathrm{q}_{\mathrm{t}}=\frac{\mathrm{q}_{\mathrm{e}}{ }^{2} \mathrm{k}_{2} \mathrm{t}}{1+\mathrm{k}_{2} \mathrm{q}_{\mathrm{e}} \mathrm{t}^{\mathrm{t}}}, \text { pseudo }- \text { sec ond order } \\
\mathrm{q}_{\mathrm{t}}=\mathrm{q}_{\mathrm{e}}-\left[\mathrm{q}_{\mathrm{e}}{ }^{1-\mathrm{n}}-(1-\mathrm{n}) \mathrm{k}_{\mathrm{n}} \mathrm{t}\right]^{1 /(1-\mathrm{n})}, \text { pseudo }- \text { nth order }
\end{gathered}
$$

where $\mathrm{q}_{\mathrm{t}}$ is the amount of adsorbed phosphate at time $\mathrm{t}, \mathrm{q}_{\mathrm{e}}$ is the amount of adsorbed phosphate at equilibrium time (both in $\mathrm{mg} \mathrm{kg}^{-1}$ soil), and $\mathrm{k}_{1}, \mathrm{k}_{2}$, and $\mathrm{k}_{\mathrm{n}}$ are the pseudo-first-order rate constant of sorption $\left(\mathrm{h}^{-1}\right)$, the pseudo-second-order rate constant of sorption $\left(\mathrm{kg} \mathrm{mg}^{-1} \mathrm{~h}^{-1}\right)$, and the pseudo-nth order rate constant of sorption $\left(\mathrm{kg}_{\mathrm{n}} \mathrm{mg}^{-\mathrm{n}} \mathrm{h}^{-1}\right)$, respectively.

The sorption isotherm can represent the distribution of phosphate between the solid and the liquid phase via linear or empirical exponential functions [23]. Often, the plot of the logarithmic adsorbed amount versus the logarithmic equilibrium concentration follows a linear function in the case of phosphate. In this research, the two widely used isotherms, Freundlich and Langmuir equations in the nonlinear form, were applied to describe the data owing to their practical model parameters, simplicity, and interpretability $[37,38]$.

$$
\begin{gathered}
\mathrm{q}_{\mathrm{e}}=\frac{\mathrm{K}_{\mathrm{L}} \mathrm{C}_{\mathrm{e}}}{1+\mathrm{K}_{\mathrm{L}} \mathrm{C}_{\mathrm{e}}} \text {, Langmuir } \\
\mathrm{q}_{\mathrm{e}}=\mathrm{K}_{\mathrm{F}} \mathrm{C}_{\mathrm{e}}{ }^{\mathrm{n}} \text {, Freundlich }
\end{gathered}
$$

where $\mathrm{q}_{\mathrm{e}}$ is the amount of adsorbed phosphate at equilibrium $\left(\mathrm{mg} \mathrm{kg}^{-1}\right), \mathrm{C}_{\mathrm{e}}$ represents the equilibrium concentration of phosphate in the solution $\left(\mathrm{mg} \mathrm{L}^{-1}\right), \mathrm{Q}$ is the Langmuir parameter, which is associated with the sorption density $\left(\mathrm{mg} \mathrm{kg}^{-1}\right)$, and $\mathrm{K}_{\mathrm{L}}$ and $\mathrm{K}_{\mathrm{F}}$ are the Langmuir and the Freundlich coefficients, respectively. $\mathrm{K}_{\mathrm{L}}$ expresses the maximum sorption capacity when $\mathrm{n}$ approaches infinity $\left(\mathrm{L} \mathrm{mg}^{-1}\right)$ and $\mathrm{K}_{\mathrm{F}}$ expresses the total sorption capacity $\left(\mathrm{L} \mathrm{kg}^{-1}\right)$, while $\mathrm{n}$ is the Freundlich constant parameter representing 
the sorption intensity (dimensionless) [39,40]. The Freundlich isotherm is an empirical model assuming that the sorption takes place on heterogeneous surfaces being predominantly chemisorption, while the Langmuir sorption considers the sorption onto homogeneous layers [40,41].

Moreover, the Langmuir equation is used to obtain the separation factor, $\mathrm{R}_{\mathrm{L}}$ :

$$
\mathrm{R}_{\mathrm{L}}=\frac{1}{1+\mathrm{K}_{\mathrm{L}} \mathrm{C}_{0}}
$$

where $\mathrm{C}_{0}\left(\mathrm{mg} \mathrm{L}^{-1}\right)$ is the initial concentration of phosphate in contact with the soil. $\mathrm{R}_{\mathrm{L}}$ values are representative for the shape of the isotherm, as $0<R_{L}<1$ imply favorable sorption, and $R_{L}>1$,

$\mathrm{R}_{\mathrm{L}}=0$ or 1 correspond to unfavorable, irreversible, and linear sorption [42].

The data validity of phosphorus sorption onto soil aggregates was checked exemplarily through the determination of the phosphorus mass balance. The total phosphorus content of soil samples after conducting the experiments was determined using microwave-assisted digestion. Subsamples of $0.5 \mathrm{~g}$ of dry soil $\left(<2 \mathrm{~mm}\right.$ ) were shaken with $100 \mathrm{~mL} \mathrm{HNO}_{3}$, and $\mathrm{HCl}$ solutions for $30 \mathrm{~min}$ and samples were centrifuged for $10 \mathrm{~min}$ and filtered (Whatman no. 42 filter). The concentrations of phosphorus were ascertained with inductively coupled plasma-optical emission spectroscopy (ICP-OES) at wavelengths of $215 \mathrm{~nm}$ (JY 238, Jobin-Yvon, France). The phosphorus amount, as determined from the soil samples, was compared to the calculated adsorbed amount using aqueous solution concentrations from the sorption experiments. In all test cases, the adsorbed phosphorus amount, as determined by soil extraction, was below the calculated amount but was always above $91 \%$ of the calculated value. This is taken as a proof, despite minor discrepancies, that the developed approach for testing phosphorus sorption onto soil aggregates is operational. MS-Excel version 2007 was employed for the fitting of kinetic and isotherm equation parameters. A T-test has been used for the comparison of phosphorus adsorption between fine soil and soil aggregates and between topsoil and subsoil at a significance level of 95\%. An F-test was performed to examine the differences of different variables as presented in Tables and Figures. All statistical analyses were performed using SPSS Statistics 22.0 software (SPSS Inc., Chicago, IL, USA).

\section{Results and Discussion}

\subsection{Pre-Test with Fine Earth}

At first, we wanted to test how the thorough shaking of a sample, as it is performed in the classical slurry batch approach, impacts the sorption process in comparison to an equilibration by diffusion. Fine earth was taken for a classical batch as well as for a diffusion experiment, and the sorption dynamic was studied over a time period of $24 \mathrm{~h}$. The differences between the moisture contents of fine earth and soil aggregates was considered throughout the experiments and the results of phosphate sorption have been adjusted accordingly. The adsorbed $\mathrm{P}$ amount similarly increased for both set-ups for the first $6 \mathrm{~h}$, although sorption of phosphate was slightly stronger if the samples were shaken (Figure 2a). Interestingly, the increase in P sorption in the classical batch experiment continued over the entire $24 \mathrm{~h}$ period by around $140 \mathrm{mg} \mathrm{kg}^{-1}$, while the adsorbed amount remained constant in the diffusion experiment after $6 \mathrm{~h}$, at just around $64 \mathrm{mg} \mathrm{kg}^{-1}$. Differences between approaches varied among the investigated concentration range after $24 \mathrm{~h}$ equilibration time (Figure $2 \mathrm{~b}$ ). At higher solution concentrations, discrepancies diminish, which could be explained by higher diffusional gradients at higher solution concentrations. 


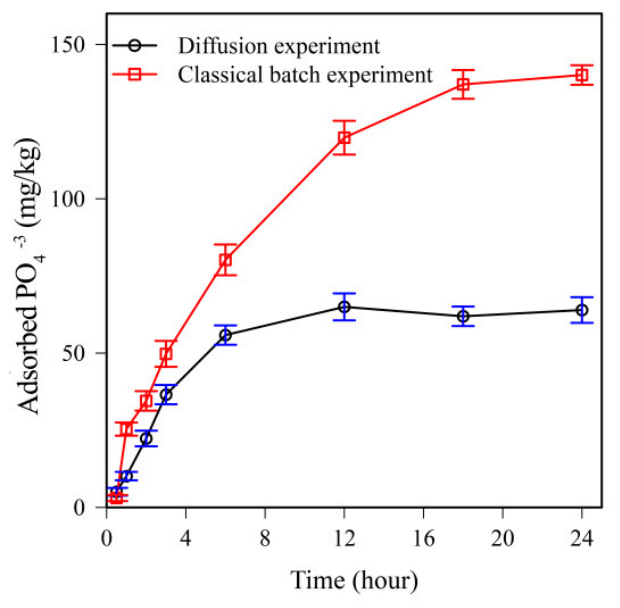

(a)

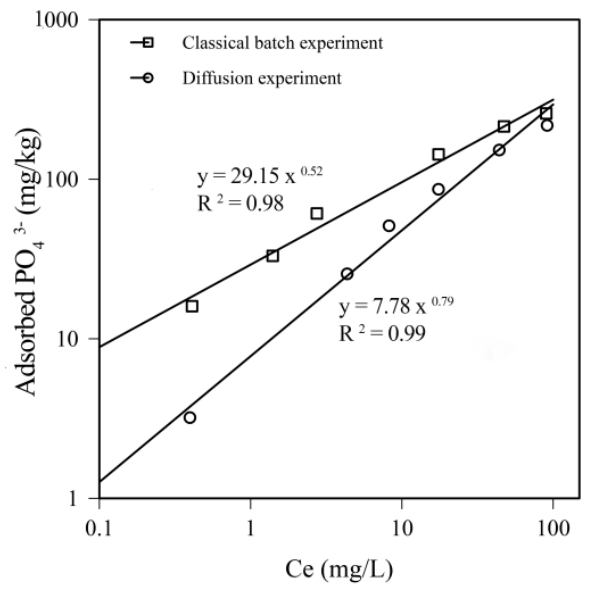

(b)

Figure 2. Impact of experimental conditions on adsorbed phosphorous $(\mathrm{P})$ amount and $\mathrm{P}$ sorption dynamic. (a) Temporal development of adsorbed $\mathrm{P}$ amount in classical batch and diffusion experiment, (b) sorption isotherm (Freundlich) from the fine earth obtained from classical batch experiment and diffusion method (Ce; equilibrium concentration; $\mathrm{PO}_{4}{ }^{3-}$; phosphate; topsoil).

It is likely that the shaker-facilitated energy input enhances sorption in general. The reason behind this is probably three-fold. The continuous shaking of the soil might rearrange soil particles, especially breaking micro-aggregates that have passed the $2 \mathrm{~mm}$ sieve intact during soil sample preparation. As a result, additional surfaces became available for sorption. In addition, constant shaking provides unlimited transport of phosphate anions in a well-mixed system to potential sorption sites, while the availability of anions might be limited in the diffusion set-up. As an additional factor, the shaking process provides an energy input into the system, which might increase the sorption capacity of phosphorus onto soil.

The observed differences in adsorbed $\mathrm{P}$ amount between approaches questions the representativeness of the classical batch sorption experiments [32,43]. Doubtlessly, the intensive mixing of soil and solution in the shaking experiments gives a sorption potential rather than a depiction of what would happen in the field [43-45]. It has to be additionally considered that experimental conditions hardly ever resemble natural conditions concerning temperature and ionic strength [44]. Depending on the purpose of the investigation, it has to be carefully weighed as to which approach is most suitable. The diffusion experiment presented here might be a reasonable alternative for both bulk and aggregated soil.

\subsection{Sorption Kinetic and Effect of Initial Concentration}

All soil aggregates remained intact throughout the experiment. For both fine earth and aggregates, a comparable temporal sorption behavior can be observed independently of the initial concentration (Figure 3). The sorption dynamic is characterized by a rapid first phase (1 to $4 \mathrm{~h}$ ) in which at least $50 \%$ of the final amount is adsorbed. In the second phase of the process, the adsorbed amount increases slowly, approaching a maximum value in an asymptotic manner $[1,46,47]$. Twenty-four hours seems to be sufficient to reach an equilibrium, which is according to pre-test experiments and in agreement with earlier studies $[25,48]$. The visual inspection of the concentration course in Figure 2a reveals that the first rapid sorption is almost similar in both experimental approaches. At later stages, however, sorption onto soil aggregates increases at a slower pace as compared to the fine earth. Differences in the temporal dynamic might have been caused by a modified diffusion process and less accessible sorption sites in case of soil aggregates. 


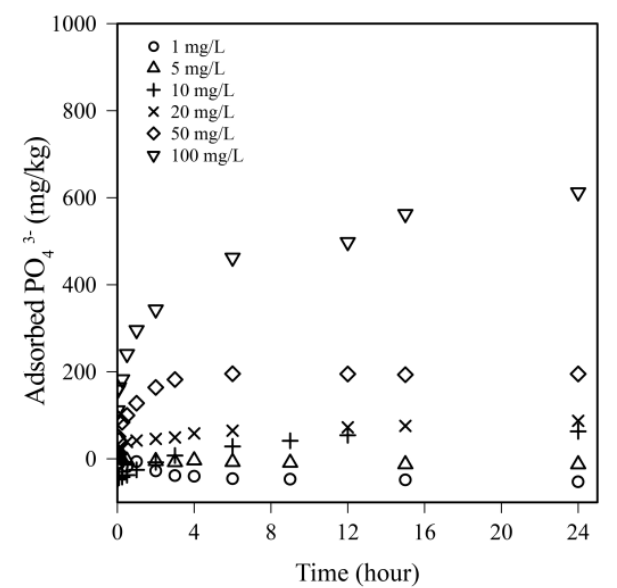

(a)

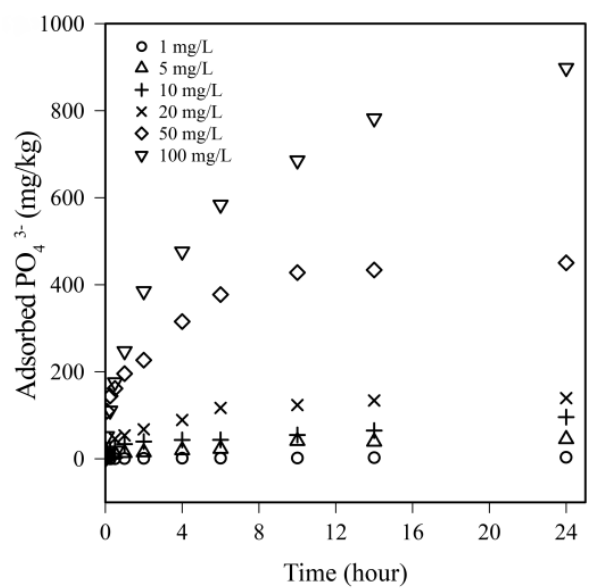

(b)

Figure 3. The effect of initial phosphate concentration on the phosphate sorption dynamic employing the diffusion approach with (a) fine earth and (b) soil aggregates (topsoil).

The results show that at low initial concentrations $\left(1\right.$ and $\left.5 \mathrm{mg} \mathrm{L}^{-1}\right), \mathrm{P}$ sorption is negative, and $P$ is released into the solution. Similar effects have been observed earlier in studies with agricultural soil [1,29]. Phosphorus desorption is to be expected if fertilized soils are investigated [29,30]. Interestingly, according to the F-test, the final adsorbed $\mathrm{P}$ amount was greater or at least equal in the aggregate case as compared to the fine earth samples, at least for the higher initial concentrations.

\subsection{Evaluation of Sorption Kinetics}

Different models were fitted to the experimental data in order to get more insight into the kinetics of the sorption process. The pseudo-first order, pseudo-second order, and the pseudo-nth order equations were tested and the parameter values, as obtained for the rate constants, are listed in Table 2.

Table 2. Optimized parameter values of the various kinetic models.

\begin{tabular}{cccccc}
\hline \multirow{2}{*}{ Model } & & \multicolumn{2}{c}{ Fine Earth } & \multicolumn{2}{c}{ Aggregates } \\
& & Topsoil & Subsoil & Topsoil & Subsoil \\
\hline \multirow{3}{*}{ Pseudo-first-order kinetic } & $\mathrm{q}_{\mathrm{e}}$ & 76 & 70 & 141 & 130 \\
& $\mathrm{k}_{1}$ & 0.55 & 0.27 & 0.13 & 0.09 \\
& $\mathrm{RMSE}$ & 154 & 41 & 65 & 53 \\
& $\mathrm{R}^{2}$ & 0.90 & 0.97 & 0.98 & 0.996 \\
& $\mathrm{q}_{\mathrm{e}}$ & 82 & 84 & 183 & 188 \\
Pseudo-second-order kinetic & $\mathrm{k}_{2}$ & 0.01 & $3.41 \times 10^{-3}$ & $6.07 \times 10^{-4}$ & $3.70 \times 10^{-4}$ \\
& $\mathrm{RMSE}$ & 83 & 40 & 66 & 53 \\
& $\mathrm{R}^{2}$ & 0.93 & 0.96 & 0.98 & 0.995 \\
& $\mathrm{~N}$ & 3.59 & 0.84 & 3.14 & 0.92 \\
Pseudo-nth-order kinetic & $\mathrm{q}_{\mathrm{e}}$ & 97 & 63 & 238 & 126 \\
& $\mathrm{k}_{\mathrm{n}}$ & $8.72 \times 10^{-6}$ & 0.5 & $8.20 \times 10^{-7}$ & 0.137 \\
& $\mathrm{RMSE}$ & 55 & 37 & 66 & 53 \\
& $\mathrm{R}^{2}$ & 0.95 & 0.98 & 0.984 & 0.996 \\
\hline
\end{tabular}

$\mathrm{q}_{\mathrm{e}}$ : The amount of adsorbed phosphate at equilibrium time $\left(\mathrm{mg} \mathrm{kg}^{-1}\right) ; \mathrm{k}_{1}$ : Pseudo-first-order rate constant of sorption $\left(\mathrm{h}^{-1}\right) ; \mathrm{k}_{2}$ : Pseudo-second-order rate constant of sorption $\left(\mathrm{kg} \mathrm{mg}^{-1} \mathrm{~h}^{-1}\right) ; \mathrm{k}_{\mathrm{n}}$ : Pseudo-nth-order rate constant of sorption $\left(\mathrm{kg}_{\mathrm{n}} \mathrm{mg}^{-\mathrm{n}} \mathrm{h}^{-1}\right)$; RMSE: root mean square error.

All tested models describe the experimental data reasonably well (Figure 4). Expectedly, among all applied models, the pseudo-nth order equation performed better than the pseudo-first and pseudo-second order, especially in the case of soil aggregates with the highest $R^{2}$ values (0.984 to 0.996 ) and lowest root mean square errors (RMSE). It should be noticed that the pseudo-nth order model 
has one more parameter compared to the other tested models and a better optimization outcome is expected. Interestingly, the fitting criteria indicated that, in general, the optimization procedure was more successful for the datasets from the subsoil samples, independent from the aggregation status of the soil.

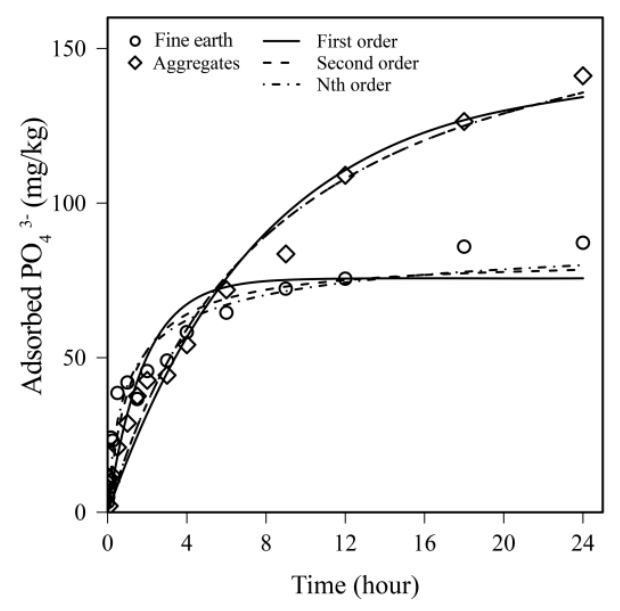

(a)

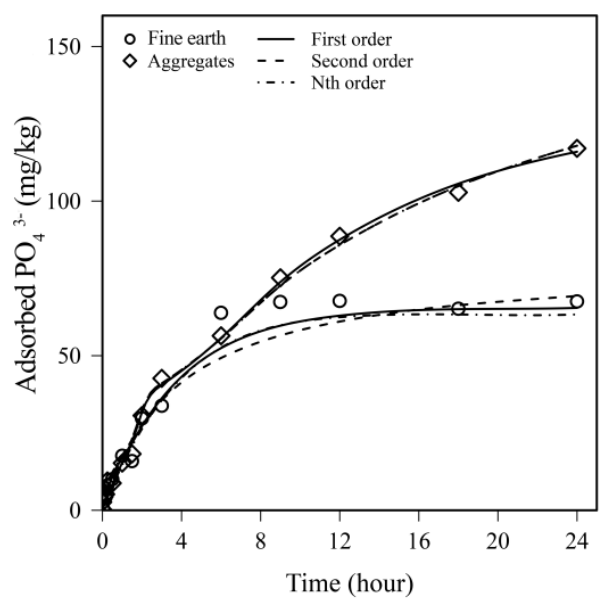

(b)

Figure 4. Phosphate sorption kinetic data and optimized model equations for aggregates and fine earth for the (a) topsoil and (b) subsoil (initial phosphate concentration of $20 \mathrm{mg} \mathrm{L}^{-1}$ ).

For topsoil, $\mathrm{q}_{\mathrm{e}}$ values, as derived from the pseudo-first order equation, were $76 \mathrm{mg} \mathrm{kg}^{-1}$ and $141 \mathrm{mg} \mathrm{kg}^{-1}$ for fine earth and soil aggregates, respectively. The elevated values of $\mathrm{q}_{\mathrm{e}}$, as found for aggregates, indicate that phosphate sorption was more pronounced for the structured soil samples than for fine earth, and statistical data from the T-test has confirmed these differences for topsoil and subsoil. The values of $k_{1}, k_{2}$, and $k_{n}$ parameters obtained from sorption kinetic models for fine earth were consistently higher, although total sorption was elevated for the soil aggregates. $\mathrm{k}$ values are interpretative for the rate of phosphate sorption: higher values indicate a steeper curve, especially at the beginning of the experiment. The more pronounced phosphate sorption of the soil aggregates that was observed is consistent with the proposed hypothesis that phosphate is not only adsorbed at accessible soil surfaces but is also retained by the intra-aggregate pore space. The assumption of a more pronounced phosphorus adsorption onto soil aggregates as compared to fine earth because of intra-aggregate retention is in agreement with Cui et al. [49], who described that macro-aggregates showed a considerable capacity to retain phosphorus in restored wetlands.

\subsection{Sorption Isotherms}

Experimental sorption data along with the Freundlich and Langmuir model optimization are given in Figure 5. It was found that for both tested soil materials, sorption onto aggregates was more pronounced than onto fine earth. Both optimized sorption equilibrium models confirm this relation. The observed impact of soil structure onto sorption capacity can probably be attributed to the inner aggregate pore space, which might accommodate phosphate molecules independent of any reactions at soil particle surfaces [50,51]. It is hypothesized that the diffusional transport of phosphate into soil aggregates lowers the phosphorous concentration in the solution, which then is counted as the adsorbed amount. It is also to be considered that the soil composition of the accessible and inner part of the aggregates might differ from the fine earth. The, in general, great heterogeneity of soil in physical, chemical, and mineralogical aspects in the solid-state, and also regarding soil solution, has to be considered in explaining the data [22,52]. Although the sorption process is predominantly assumed to be a surface phenomenon $[25,53]$, structured soils may withdraw molecules from the advectively moving soil water. In experimental solute transport studies, the combined effect of surface sorption and 
diffusional retention into aggregate pore space results in a later breakthrough and probably stronger tailing of a breakthrough curve [50].

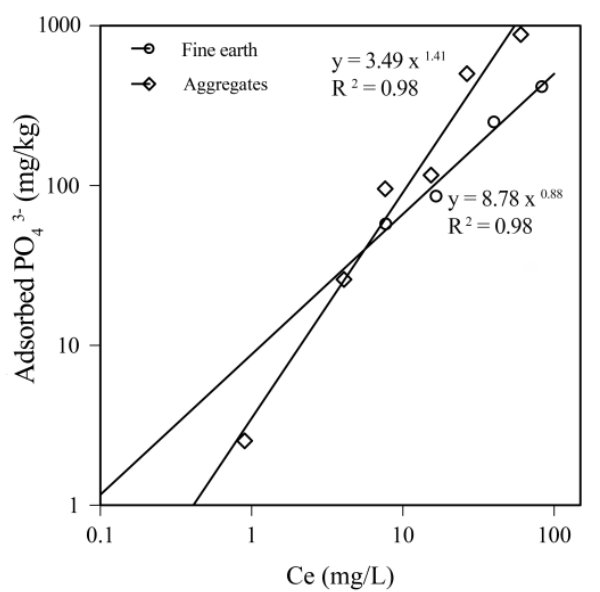

(a)

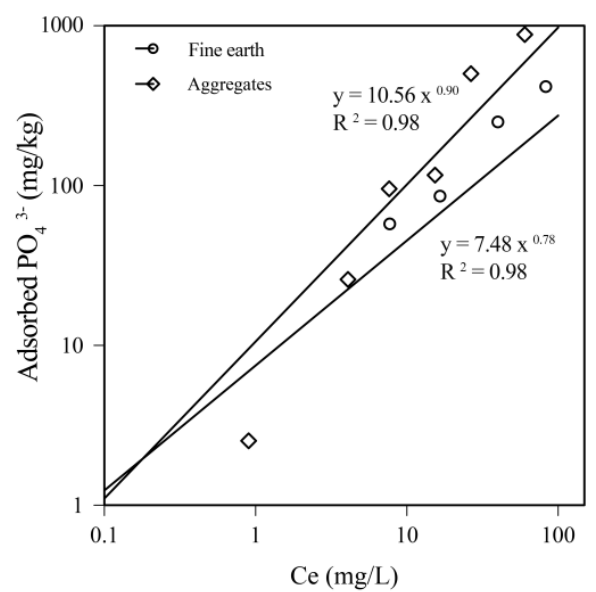

(b)

Figure 5. Sorption isotherms of phosphate for samples from (a) topsoil and (b) subsoil horizons.

Phosphorus sorption was found to be higher for the subsoil, for fine earth and soil aggregates, which is in agreement with the clay content of the two tested materials (Table 1). It has been clearly demonstrated earlier that the adsorbed phosphate amount is firmly, positively related to the clay content because of the high surface area and according soil buffering capacity [54]. Although the subsoil had a higher clay content, less phosphate was adsorbed. The reason behind this is not fully understood but might be related to the blockage of reactive clay surfaces for adsorption of phosphorus through coating of the specific sorption sites by soil organic matter [32,55].

The parameter values computed employing the isotherm models and the coefficients of determination are displayed in Table 3. Both models were capable of describing the experimental data, although the Freundlich approach gave more accurate results according to the greater values of $R^{2}$. As anticipated, the Freundlich sorption capacity, $\mathrm{K}_{\mathrm{F}}$, of soil aggregate $\left(12.61 \mathrm{~L} \mathrm{~kg}^{-1}\right.$ for topsoil and $16.95 \mathrm{~L} \mathrm{~kg}^{-1}$ for subsoil) is large compared with that of fine earth (7.66 for topsoil and 11.48 for subsoil).

Table 3. Sorption Freundlich and Langmuir isotherm data.

\begin{tabular}{llccccccccc}
\hline & & \multicolumn{4}{c}{ Freundlich } & \multicolumn{4}{c}{ Langmuir } \\
& & $\mathbf{K}_{\mathbf{F}}$ & $\mathbf{n}_{\mathbf{F}}$ & $\mathbf{R M S E}$ & $\mathbf{R}^{2}$ & $\mathbf{K}_{\mathbf{L}}$ & $\mathbf{Q}_{\mathbf{L}}$ & $\mathbf{R}_{\mathbf{L}}$ & $\mathbf{R M S E}$ \\
\hline \multirow{2}{*}{ Fine earth } & Topsoil & 7.66 & 0.80 & 246.7 & 0.976 & 0.03 & 161.8 & $0.25-0.97$ & 14.07 & 0.965 \\
& Subsoil & 11.48 & 0.56 & 139.2 & 0.989 & 0.02 & 114.7 & $0.33-0.98$ & 10.48 & 0.957 \\
& Topsoil & 12.61 & 0.94 & 505.9 & 0.966 & 0.05 & 272.3 & $0.17-0.95$ & 20.64 & 0.960 \\
& Subsoil & 16.95 & 0.85 & 343.2 & 0.997 & 0.03 & 190.9 & $0.25-0.98$ & 16.68 & 0.977 \\
\hline
\end{tabular}

In the case of the Langmuir model, the $\mathrm{K}_{\mathrm{L}}$ values ranged from 0.02 to 0.05 (Table 3), which implies favorable sorption conditions for phosphate on fine earth and aggregates. The sorption density, $\mathrm{Q}_{\mathrm{L}}$, ranged from 114.7 to $272.3 \mathrm{mg} \mathrm{kg}^{-1}$ and was greater for aggregates than for the fine earth for both tested materials. The $\mathrm{R}_{\mathrm{L}}$ values fell between 0 and 1 , which demonstrates the favorable sorption of phosphate onto fine earth and aggregates. Furthermore, the $\mathrm{R}_{\mathrm{L}}$ values show that the sorption of phosphate was more favorable for the lower than for the higher concentrations, $\mathrm{C}_{0}=1 \mathrm{mg} \mathrm{L}^{-1}:=0.97$ (fine earth, topsoil), 0.98 (fine earth, subsoil), 0.95 (aggregates, topsoil), 0.98 (aggregates, subsoil), and $\mathrm{C}_{0}=100 \mathrm{mg} \mathrm{L}^{-1}: \mathrm{R}_{\mathrm{L}}=0.25$ (fine earth, topsoil), 0.33 (fine earth, subsoil), 0.17 (aggregates, topsoil), 0.25 (aggregates, subsoil), which is due to the decrease of surface affinity at increasing phosphorus concentrations. This is a well-known phenomenon, generally attributed to the saturation of high-affinity 
binding sites and the increasing of the electrostatic barriers as negatively charged phosphate binds to the surfaces of soil [56].

\section{Conclusions}

In this study, the phosphate sorption onto fine earth and aggregates was investigated to clarify the importance of soil structure on the process. The results showed that the sorption onto soil aggregates was elevated as compared to unstructured fine earth, even if the same experimental time period was observed. Compared to fine earth, the more pronounced sorption of phosphate onto aggregates demonstrates the importance of soil structure for soil chemical processes in general. We assume that the inner pore space of soil aggregates is an accommodation space for phosphate molecules besides the adsorbed amount. In such a situation, the sorption capacity of intact aggregates might be higher than that of the disturbed soil. The nth-pseudo sorption rate equation provided a superior fit to data, explaining the idea of the heterogeneity of soil surfaces for phosphate sorption. Moreover, the sorption of phosphate onto fine earth and aggregates was found to be strongly dominated by the initial phosphate concentration. The present study introduced a new approach to investigate sorption phenomena in structured soil, which is believed to more closely compare to natural circumstances as they might occur in the field. Many open questions remain, however. The results highlighted the importance of soil structure onto phosphate sorption for a soil with low organic and clay content. A thorough testing of the new approach shall reveal its applicability to a wide range of soils and chemical compounds. Also, aggregate size and according diffusion path length should be more closely considered in future studies, as some studies have highlighted that the distribution and release of phosphorus in restored wetlands are associated with the size of soil aggregates [51]. Soil studies at the molecular level and phosphorus chemisorption on a number of soil minerals can improve insights into the phosphorus adsorption mechanism in soil for the proposed experiment.

Supplementary Materials: The following materials are available online at http:/www.mdpi.com/2571-8789/4/ 2/21/s1: Figure S1: Adsorbed phosphate amount as a function of experimental duration for fine earth and soil aggregates, Table S1: Some chemical characteristics of the experimental field.

Author Contributions: H.S. conducted the research (data collection, calculation, and analysis), reviewed the literature, and drafted the manuscript; H.L. computed the figures and updated the literature; B.L. supervised the study and thoroughly revised the article. All authors have read and agreed to the published version of the manuscript.

Funding: This research was funded by the German Federal Ministry of Education and Research (BMBF) under PhosWaM-From source to sea-Integrated phosphorus and water resources management for sustainable water protection, grant number 64130151 and InnoSoilPhos-Innovative solutions to sustainable Soil Phosphorus management, grant number 64130141.

Conflicts of Interest: The authors do not have any conflicts of interest to declare.

\section{References}

1. Barrow, N.J. A mechanistic model for describing the sorption and desorption of phosphate by soil. Eur. J. Soil Sci. 2015, 66, 9-18. [CrossRef]

2. Van Der Salm, C.; Kros, J.; de Vries, W. Evaluation of different approaches to describe the sorption and desorption of phosphorus in soils on experimental data. Sci. Total Environ. 2016, 571, 292-306. [CrossRef] [PubMed]

3. Xia, Y.; Zhang, M.; Tsang, D.C.W.; Geng, N.; Lu, D.; Zhu, L.; Igalavithana, A.D.; Dissanayake, P.D.; Rinklebe, J.; Yang, X. Recent advances in control technologies for non-point source pollution with nitrogen and phosphorous from agricultural runoff: Current practices and future prospects. Appl. Biol. Chem. 2020, 63, 1-13. [CrossRef]

4. Xiao, Y.; Tang, J.; Wang, M.; Zhai, L.; Zhang, X. Impacts of soil properties on phosphorus adsorption and fractions in purple soils. J. Mt. Sci. 2017, 14, 2420-2431. [CrossRef]

5. Ho, Y.S.; McKay, G. Kinetic models for the sorption of dye from aqueous solution by wood. Process Saf. Environ. 1998, 76, 183-191. [CrossRef] 
6. Del Bubba, M.; Arias, C.A.; Brix, H. Phosphorus adsorption maximum of sands for use as media in subsurface flow constructed reed beds as measured by the Langmuir isotherm. Water Res. 2003, 37, 3390-3400. [CrossRef]

7. Samadi, A.; Gilkes, R.J. Phosphorus transformations and their relationships with calcareous soil properties of southern Western Australia. Soil Sci. Soc. Am. J. 1999, 63, 809-815. [CrossRef]

8. Singh, B.; Gilkes, R.J. Phosphorus sorption in relation to soil properties for the major soil types of South-Western Australia. Soil Res. 1991, 29, 603-618. [CrossRef]

9. Akhtar, M.S.; Richards, B.K.; Medrano, P.A.; DeGroot, M.; Steenhuis, T.S. Dissolved phosphorus from undisturbed soil cores. Soil Sci. Soc. Am. J. 2003, 67, 458-470. [CrossRef]

10. Lal, R.; Shukla, M.K. Principles of Soil Physics; Marcel Dekker Inc.: New York, NY, USA, 2004; ISBN 0-82475324-0.

11. Peth, S.; Horn, R.; Beckmann, F.; Donath, T.; Fischer, J.; Smucker, A.J.M. Three-dimensional quantification of intra-aggregate pore-space features using synchrotron-radiation-based microtomography. Soil Sci. Soc. Am. J. 2008, 72, 897-907. [CrossRef]

12. Kausch, M.; Ng, P.; Ha, J.; Pallud, C. Soil-aggregate-scale heterogeneity in microbial selenium reduction. Vadose Zone J. 2012, 11. [CrossRef]

13. Horn, R. Aggregate characterization as compared to soil bulk properties. Soil Tillage Res. 1990, 17, $265-289$. [CrossRef]

14. Prutton, C.F.; Maron, S.H. Fundamental Principles of Physical Chemistry; Macmillan Co.: New York, NY, USA, 1953.

15. Temminghoff, E.J.M.; Weng, L.; Kalis, E.J.J.; Van Riemsdijk, W.H. Process-based approach in the study of ions in soils. In Development of soil science; Elsevier Ltd.: Amsterdam, The Netherlands, 2008; Volume 32, pp. 137-167. [CrossRef]

16. Trivedi, P.; Axe, L. Modeling Cd and Zn sorption to hydrous metal oxides. Environ. Sci. Technol. 2000, 34, 2215-2223. [CrossRef]

17. Lin, T.F.; Wu, J.K. Adsorption of arsenite and arsenate within activated alumina grains: Equilibrium and kinetics. Water Res. 2001, 35, 2049-2057. [CrossRef]

18. Kravchenko, A.N.; Negassa, W.C.; Guber, A.K.; Rivers, M.L. Protection of soil carbon within macro-aggregates depends on intra-aggregate pore characteristics. Sci. Rep. 2015, 5, 16261. [CrossRef]

19. Southam, D.C.; Lewis, T.W.; McFarlane, A.J.; Johnston, J. Amorphous calcium silicate as a biosorbent for phosphate. Curr. Appl. Phys. 2004, 4, 355-358. [CrossRef]

20. Liu, H.; Sun, X.; Yin, C.; Hu, C. Removal of phosphate by mesoporous $\mathrm{ZrO}_{2}$. J. Hazard. Mat. 2008, 151, 616-622. [CrossRef]

21. Yang, X.; Chen, X.; Yang, X. Effect of organic matter on phosphorus adsorption and desorption in a black soil from Northeast China. Soil Tillage Res. 2019, 187, 85-91. [CrossRef]

22. Van Der Zee, S.E.A.T.M.; Van Riemsdijk, W.H. Sorption kinetics and transport of phosphate in sandy soil. Geoderma 1986, 38, 293-309. [CrossRef]

23. Barrow, N.J. The description of phosphate adsortion curves. J. Soil Sci. 1978, 29, 447-462. [CrossRef]

24. Streck, T.; Poletika, N.; Jury, W.A.; Farmer, W.J. Description of simazine transport with rate-limited, two-stage, linear and nonlinear sorption. Water Resour. Res. 1995, 31, 811-822. [CrossRef]

25. Köhne, J.M.; Gerke, H.; Köhne, S. Effective diffusion coefficients of soil aggregates with surface skins. Soil Sci. Soc. Am. J. 2002, 66, 1430-1438. [CrossRef]

26. Zhou, M.; Li, Y. Phosphorus-sorption characteristics of calcareous soils and limestone from the southern everglades and adjacent farm lands. Soil Sci. Soc. Am. J. 2001, 65, 1404-1412. [CrossRef]

27. Naeem, A.; Akhtar, M.; Top soilmad, W. Optimizing available phosphorus in calcareous soils fertilized with diammonium phosphate and phosphoric acid using Freundlich adsorption isotherm. Sci. World J. 2013, 680257. [CrossRef] [PubMed]

28. Abdelwaheb, M.; Jebali, K.; Dhaouadi, H.; Dridi-Dhaouadi, S. Adsorption of nitrate, phosphate, nickel and lead on soils: Risk of groundwater contamination. Ecotoxicol. Environ. Saf. 2019, 179, 182-187. [CrossRef] [PubMed]

29. Barrow, N.J. Soil phosphate chemistry and the P-sparing effect of previous phosphate applications. Plant Soil 2015, 397, 401-409. [CrossRef]

30. Barrow, N.J.; Debnath, A. Effect of phosphate status on the sorption and desorption properties of some soils of northern India. Plant Soil 2014, 378, 383-395. [CrossRef] 
31. Vaughn, E.B.; Jimmy, J.S.; Rao, P.S.C.; Yuan, T.L. Partitioning of inorganic orthophosphate in soil-water systems. Crit. Rev. Environ. Control 1980, 10, 179-224. [CrossRef]

32. Linquist, B.A.; Singleton, P.W.; Yost, R.S.; Cassman, K.G. Aggregate size effects on the sorption and release of phosphorus in an Ultisol. Soil Sci. Soc. Am. J. 1997, 61, 160-166. [CrossRef]

33. IUSS Working Group WRB. World Reference Base for Soil Resources 2014, Update 2015: International Soil Classification System for Naming Soils and Creating Legends for Soil Maps; World Soil Resources Reports No. 106; FAO: Rome, Italy, 2015; p. 192.

34. Murphy, J.; Riley, J.P. A modified single solution method for the determination of phosphate in natural waters. Anal. Chem. ACTA 1962, 27, 31-36. [CrossRef]

35. Lagergren, S.K. About the theory of so-called adsorption of soluble substances. Sven. Vetenskapsakad. Handingarl 1898, 24, 1-39.

36. Özer, A. Removal of $\mathrm{Pb}(\mathrm{II})$ ions from aqueous solutions by sulphuric acid-treated wheat bran. J. Hazard. Mater. 2007, 141, 753-761. [CrossRef] [PubMed]

37. Tran,H.N.; You, S.J.; Hosseini-bandegharaei, A.; Chao, H.P. Mistakes and inconsistencies regarding adsorption of contaminants from aqueous solutions: A critical review. Water Res. 2017, 120, 88-116. [CrossRef] [PubMed]

38. Hubbe, M.A.; Azizian, S.; Douven, S. Implications of apparent pseudo-second-order adsorption kinetics onto cellulosic materials: A review. BioResources 2019, 14, 7582-7626.

39. Goldberg, S. Equations and models describing adsorption processes in soils. In Chemical Processes in Soils; American Society of Agronomy: Madison, WI, USA, 2005; pp. 489-518.

40. Freundlich, H.; Heller, W. The adsorption of cis- and trans-azobenzene. J. Am. Chem. Soc. 1939, 61, $2228-2230$. [CrossRef]

41. Langmuir, I. The adsorption of gases on plane surfaces of glass, mica and platinum. J. Am. Chem. Soc. 1918, 40,1361-1403. [CrossRef]

42. Alemayehu, E.; Sören, T.B.; Lennartz, B. Adsorption behaviour of Cr (VI) onto macro and micro-vesicular volcanic rocks from water. Sep. Purif. Technol. 2011, 78, 55-61. [CrossRef]

43. Van Grinsven, J.J.M.; van Riemsdijk, W.H. Evaluation of batch and column techniques to measure weathering rates in soils. Geoderma 1992, 52, 41-57. [CrossRef]

44. Pačes, T. Rate constants of dissolution derived from the measurements of mass balance in hydrological catchments. Geochim. Cosmochim. Acta 1983, 47, 1855-1863. [CrossRef]

45. Velbel, M.A. Influence of surface area, surface characteristics, and solution composition on Feldspar weathering rates. In Geochemical Processes at Mineral Surfaces; American Chemical Society: Washington, DC, USA, 1987; pp. 615-634.

46. Fink, J.R.; Inda, A.V.; Bavaresco, J.; Barro, V. Phosphorus adsorption and desorption in undisturbed samples from subtropical soils under conventional tillage or no-tillage. J. Plant Nutr. Soil Sci. 2016, 179, $198-205$. [CrossRef]

47. Do Carmo Horta, M.; Torrent, J. Phosphorus desorption kinetics in relation to phosphorus forms and sorption properties of Portuguese scid soils. Soil Sci. 2007, 172, 631-638. [CrossRef]

48. Yao, Y.; Gao, B.; Inyang, M.; Zimmerman, A.R.; Cao, X.; Pullammanappallil, P.; Yang, L. Removal of phosphate from aqueous solution by biochar derived from anaerobically digested sugar beet tailings. J. Hazard. Mater. 2011, 190, 501-507. [CrossRef] [PubMed]

49. Cui, H.; Ou, Y.; Wang, L.; Wu, H.; Yan, B.; Li, Y. Distribution and release of phosphorus fractions associated with soil aggregate structure in restored wetlands. Chemosphere 2019, 223, 319-329. [CrossRef] [PubMed]

50. Lee, S.H.; Vigneswaran, S.; Moon, H. Adorption of phosphorus in saturated slag media columns. Sep. Purif. Technol. 1997, 12, 109-118. [CrossRef]

51. Wang, S.; He, X.; Ye, S. Soil aggregation and aggregate-associated carbon, nitrogen, and phosphorus under different aged tea (Camellia sinensis L.) plantations in hilly region of southern Guangxi, China. Sci. Hortic. 2020, 262, 109007. [CrossRef]

52. Santos, H.C.; Oliveira, F.H.T.D.; Salcedo, I.H.; Souza, A.P.D.; Silva, M. Kinetics of phosphorus sorption in soils in the state of Paraíba. Rev. Bras. Ciência Solo 2011, 35, 1301-1310. [CrossRef]

53. Wang, X.; Yost, R.S.; Linquist, B.A. Soil aggregate size affects phosphorus desorption from highly weathered soils and plant growth. Soil Sci. Soc. Am. J. 2001, 65, 139-146. [CrossRef]

54. Cox, F.R. Predicting increases in extractable phosphorus from fertilizing soils of varying clay content. Soil Sci. Soc. Am. J. 1994, 58, 1249-1253. [CrossRef] 
55. Dubus, I.G.; Barriuso, E.; Calvet, R. Sorption of weak organic acids in soils: Clofencet, 2,4-D and salicylic acid. Chemosphere 2001, 45, 767-774. [CrossRef]

56. Celi, L.; Lamacchia, S.; Marsan, F.A.; Barberis, E. Interaction of inositol hexaphosphate on clays: Adsorption and charging phenomena. Soil Sci. 1999, 164, 574-585. [CrossRef]

(C) 2020 by the authors. Licensee MDPI, Basel, Switzerland. This article is an open access article distributed under the terms and conditions of the Creative Commons Attribution (CC BY) license (http://creativecommons.org/licenses/by/4.0/). 